\title{
KOMPARASI DISPOSISI MATEMATIS PADA SISWA BERKEPRIBADIAN MELANKOLIS DAN SANGUINIS
}

\author{
Saryati $^{1^{*}}$, Budiyono ${ }^{1}$, Riawan Yudi Purwoko ${ }^{1}$, Teguh Wibowo ${ }^{1}$ \\ ${ }^{1}$ Universitas Muhammadiyah Purworejo \\ Corresponding Author: saryati144@gmail.com*
}

\begin{abstract}
The purpose of this study was to determine the mathematical disposition of students who have sanguine and melancholic personality types, and whether the mathematical disposition of students with sanguine types is higher than melancholic types. The population in this study was 260 seventh grade students of Junior High School in the Piturub district. Sampling using a proportionate random sampling technique was taken as many as 65 students. Data collection was carried out using questionnaires and tests. The results of the first study showed that the mathematical disposition of seventh-grade students in the Piturub Subdistrict in the 2019 school year in terms of the sanguine and melancholic personality types of more than 60\%. The second research result shows that there are differences in mathematical disposition between sanguine and melancholic types, where the mathematical disposition of students with sanguine personality types is higher than students with melancholic personality types.
\end{abstract}

Keywords: Mathematical disposition; Melancholic; Sanguine

How to cite: Saryati, Budiyono, Purwoko, R. Y., \& Wibowo, T. (2020). Komparasi Disposisi Matematis pada Siswa Berkepribadian Sanguinis dan Melankolis. JRPM (Jurnal Review Pembelajaran Matematika), 5(1), 66-71.

\section{PENDAHULUAN}

Disposisi matematis diartikan sebagai sikap siswa yang cenderung positif terhadap pembelajaran matematika. Seperti yang dijelaskan oleh Sukamto (2013), disposisi matematis adalah kecenderungan untuk berpikir dan bertindak secara positif. Sikap positif yang dimaksud dalam pembelajaran matematika seperti rasa percaya diri, gigih dan rasa keingintahuan dari siswa tentang matematika. Senada dengan hal tersebut Sumarmo et al (2012) mendefinisikan bahwa disposisi matematis yaitu keinginan, kesadaran, kecenderungan dan dedikasi yang kuat peserta didik untuk berpikir dan berbuat secara matematik dengan cara yang positif.

Selain itu Killpatrick mendefinisikan disposisi matematis atau disposisi produktif yaitu kecenderungan dalam memandang matematika sebagai sesuatu yang mudah dipahami, merasakan matematika sebagai ilmu yang berguna, meyakini usaha yang tekun dan ulet dalam belajar matematika membuahkan hasil, serta melakukan kegiatan berbasis matematika (Prasetyo, Dwidayati, \& Junaedi, 2017). Seorang siswa yang memiliki disposisi matematis biasanya mempunyai sikap kegigihan yang tinggi untuk menyelesaikan permasalahan yang mereka hadapi dalam pembelajaran matematika. 
Berdasarkan hasil pra penelitian, diperoleh gambaran bahwa disposisi matematis beberapa siswa masih kurang baik dalam proses pembelajaran. Hal ini dikarenakan pada saat mengerjakan soal matematika siswa kurang percaya diri, siswa kurang gigih dalam mencari solusi penyelesaian soal matematika serta kurangnya keingintahuan siswa dalam belajar matematika. Selain faktor dari dalam diri siswa, kemungkinan guru juga mengambil peran penting dalam proses pembelajaran. Disposisi matematis sebenarnya sangat penting untuk ditingkatkan, tetapi kadang kurang diperhatikan oleh guru. Nilai akhir siswa masih menjadi tolak ukur bagi guru untuk menilai kemampuan siswa, padahal yang terpenting sebenarnya adalah proses bagaimana siswa mampu mendapatkan nilai tersebut.

Fakta rendahnya disposisi matematis siswa juga dapat dilihat dari hasil penelitian Diningrum, Azhar, dan Faradillah (2018), yang mendapatkan skor rerata disposisi matematis 52 padahal skor tertingginya 108. Penyebab disposisi matematis rendah dikarenakan siswa tidak mempunyai sikap yang positif terhadap matematika. Dari fakta tersebut, maka untuk mendapatkan hasil yang maksimal dalam pembelajaran matematika, seorang siswa harus mempunyai disposisi matematis yang baik, karena untuk memahami konsep matematika yang abstrak diperlukan sikap percaya diri, gigih dan rasa keingintahuan tentang matematika.

Selain disposisi matematis yang harus dimiliki siswa, karakteristik siswa juga berpengaruh dalam proses pembelajaran khususnya pada matematika. Karakteristik yang pasti dimiliki oleh siswa yaitu kepribadian. Sjarkawi (2006) mendefinisikan kepribadian sebagai ciri atau karakteristik atau gaya atau sifat khas dari diri seseorang yang bersumber dari bentukan-bentukan yang diterima dari lingkungan. Oleh karena itu, kepribadian antara satu orang dengan orang lain pasti berbeda. Seperti yang dikemukakan oleh Liaw (2010) bahwa setiap orang berperilaku berbeda-beda sesuai dengan kepribadian yang dibangun dan dibentuk sepanjang perjalanan hidupnya. Tipe kepribadian yang berbeda-beda antara satu siswa dengan siswa lainnya akan berpengaruh pada proses pembelajaran matematika. Dengan kata lain disposisi matematis siswa tidak lepas dari peranan tipe kepribadian.

Berdasarkan definisi kepribadian tersebut, maka dapat digolongkan tipe kepribadian yang umumnya sudah dikenal dalam kehidupan sehari-hari. Seperti yang dikembangkan oleh Galenus yang membagi kepribadian menjadi 4 tipe, yaitu: sanguinis, melankolis, koleris dan pleghmatis (Yusuf \& Nurihsan, 2017). Dalam penelitian ini peneliti hanya mengambil dua tipe kepribadian yaitu tipe sanguinis dan melankolis. Hal ini karena kedua tipe tersebut termasuk kepribadian yang berlawanan sehingga sangat menarik untuk diteliti. Tipe sanguinis 
suatu kepribadian yang periang, optimis dan percaya diri, sedangkan melankolis suatu kepribadian yang tertutup atau berbanding terbalik dengan tipe sanguinis.

Berdasarkan hasil penelitian Prasetyo et al (2017) tentang kemampuan koneksi matematis dan disposisi matematis siswa di SMP N 1 Selogiri kelas VII B ditinjau dari kepribadian Keirsey pada pembelajaran matematika model eliciting activities, menunjukkan bahwa (1) hasil koneksi matematis siswa tipe Artisan dalam kategori sedang, memenuhi 1 sampai 2 indikator dan tingkat disposisi matematis juga sedang; (2) tipe Guardion masuk kategori rendah hanya menguasai satu indikator dan tingkat disposisinya sedang; (3) tipe Idealist masuk dalam kategori tinggi yaitu menguasai 3 sampai 4 indikator dan tingkat disposisi matematis sangat tinggi; (4) tipe Rational kategori tinggi yakni menguasai keempat indikator dan disposisi matematisnya tinggi.

Selanjutnya penelitian Wardani (2017) tentang perbandingan hasil belajar biologi antara siswa kepribadian sanguinis dan kepribadian melankolis, menunjukkan bahwa terdapat perbedaan hasil belajar biologi antara siswa kepribadian sanguinis dengan siswa kepribadian melankolis, dimana hasil belajar biologi siswa dengan kepribadian melankolis lebih tinggi dari pada hasil belajar biologi siswa dengan kepribadian sanguinis. Berdasarkan penelitian-penelitian tersebut, dapat disimpulkan bahwa tipe kepribadian yang berbeda dari masing-masing siswa akan mempengaruhi proses pembelajaran. Sehingga fokus pada penelitian ini yaitu tentang perbedaan disposisi matematis siswa dilihat dari tipe kepribadian sanguinis dan tipe kepribadian melankolis. Tujuan penelitian ini adalah untuk mengetahui: (1) disposisi matematis siswa yang mempunyai tipe kepribadian sanguinis; (2) disposisi matematis siswa yang mempunyai tipe kepribadian melankolis; (3) apakah disposisi matematis siswa yang bertipe kepribadian sanguinis lebih baik daripada siswa dengan tipe kepribadian melankolis. Penelitian ini diharapkan memberikan informasi mengenai pentingnya disposisi matematis apabila ditinjau dari tipe kepribadian sanguinis dan tipe kepribadian melankolis.

\section{METODE PENELITIAN}

Metode penelitian yang digunakan dalam penelitian ini adalah metode penelitian kuantitatif, dengan jenis penelitian komparasi. Menurut Sugiyono (2016), penelitian komparasi bermaksud membandingkan nilai satu atau lebih variabel mandiri pada dua atau lebih populasi, sampel atau waktu yang berbeda atau gabungan semuanya. Penelitian ini dilakukan pada siswa kelas VII SMP se-Kecamatan Pituruh kurang lebih 11 bulan yaitu 
bulan Oktober 2018-Agustus 2019. Populasi dalam penelitian ini adalah seluruh siswa kelas VII SMP se-Kecamatan Pituruh sebanyak 260 siswa dengan sampel 65 siswa. Pengambilan sampel menggunakan teknik proportionate random sampling. Pengumpulan data dilakukan dengan menggunakan angket dan tes. Pengolahan data menggunakan uji prasyarat dan uji hipotesis. Untuk uji prasyarat yang digunakan yaitu uji normalitas dengan metode Chi Square dan uji homogenitas dengan uji F. Uji hipotesis dalam penelitian ini yaitu uji hipotesis deskriptif dan komparasi.

\section{HASIL DAN PEMBAHASAN}

Hasil penelitian diperoleh dari instrumen penelitian yang dilaksanakan di SMP seKecamatan Pituruh. Data yang diperoleh meliputi disposisi matematis siswa tipe sanguinis dan tipe melankolis. Berdasarkan data disposisi matematis diperoleh rerata, varians dan standar deviasi yang disajikan dalam Tabel 1 sebagai berikut.

Tabel 1. Rerata, Varians dan Standar Deviasi Skor Disposisi Matematis

\begin{tabular}{ccc}
\hline Statistik & $\begin{array}{c}\text { Disposisi Matematis Siswa Tipe } \\
\text { Sanguinis }\end{array}$ & $\begin{array}{c}\text { Disposisi Matematis Siswa Tipe } \\
\text { Melankolis }\end{array}$ \\
\hline $\bar{x}$ & 28,83 & 27,80 \\
$s^{2}$ & 11,09 & 14,90 \\
$s$ & 3,33 & 3,86 \\
\hline
\end{tabular}

Pada Tabel 1 didapatkan skor rerata disposisi matematis siswa tipe sanguinis lebih tinggi dibandingkan skor rerata disposisi matematis siswa tipe melankolis. Untuk mengetahui apakah disposisi matematis siswa dengan kepribadian sanguinis dan melankolis lebih dari $60 \%$ perlu dilakukan statistik uji-t. Hasil pengolahan data dapat dilihat dalam Tabel 2 berikut.

Tabel 2. Data Deskriptif Disposisi Matematis Siswa

\begin{tabular}{lccc}
\hline \multicolumn{1}{c}{ Kelompok Siswa } & $\mathrm{t}_{\text {hitung }}$ & $\mathrm{t}_{\text {tabel }}$ & Kesimpulan \\
\hline Sanguinis & $-2,08$ & 1,66 & Ho ditolak \\
Melankolis & $-3,29$ & 1,66 & Ho ditolak \\
\hline
\end{tabular}

Berdasarkan hasil perhitungan uji-t di atas dapat dikatakan bahwa nilai $t_{\text {hitung }}<t_{\text {tabel. }}$ Oleh karena itu, $\mathrm{H}_{0}$ ditolak. Artinya bahwa disposisi matematis siswa dengan tipe kepribadian sanguinis dan melankolis lebih dari $60 \%$. Hal ini berarti siswa dengan tipe kepribadian sanguinis dan melankolis masuk dalam kategori baik. Selanjutnya untuk menguji apakah disposisi matematis siswa yang mempunyai tipe kepribadian sanguinis lebih baik dari tipe melankolis.

Pengujian komparasi dengan taraf signifikan 0,05 dilakukan dengan uji t pihak kanan 
yang menghasilkan $t_{\text {hitung }}$ sebesar 1,78. Kemudian dibandingkan dengan $t_{\text {tabel }}$ sebesar 1,66. Setelah dibandingkan ternyata $t_{\text {hitung }}$ lebih besar dari tabel maka $\mathrm{H}_{0}$ ditolak. Hasil yang diperoleh menunjukkan bahwa disposisi matematis siswa yang mempunyai tipe kepribadian sanguinis lebih baik dari tipe melankolis. Pada kelompok siswa dengan tipe kepribadian sanguinis berada pada kategori tinggi dibandingkan siswa dengan tipe melankolis. Hal tersebut dapat dilihat dari hasil perolehan skor rata-rata disposisi matematis siswa tipe sanguinis sebesar 28,83 sedangkan siswa dengan tipe melankolis 27,80. Kesimpulannya bahwa siswa dengan tipe sanguinis memiliki skor rata-rata disposisi matematis lebih tinggi dari pada siswa dengan tipe melankolis. Hal Tersebut senada dengan penelitian yang dilakukan oleh Winarso (2015) bahwa rata-rata sikap belajar yang dimiliki siswa dengan tipe sanguinis lebih tingi daripada tipe melankolis.

Secara teoritis ciri-ciri umum tipe kepribadian sanguinis menurut Littauer (2011) yaitu suatu kepribadian yang menarik, antusias dan ekspresif, penuh rasa ingin tahu. Tipe kepribadian sanguinis yang sangat antusias dan mempunyai rasa ingin tahu yang tinggi, akan berusaha menyelesaikan masalah yang sedang dihadapi, begitupun juga dengan pembelajaran matematika, siswa dengan tipe ini cenderung lebih semangat untuk menemukan jawaban soal matematika walaupun itu sulit. Berbeda dengan tipe melankolis yang kurang begitu antusias dalam menyelesaikan soal matematika.

Galenus mendefinisikan kepribadian melankolis sebagai kepribadian yang bertolak belakang dari kepribadian sanguinis (Yusuf \& Nurihsan, 2017). Suatu karakter yang pemurung, sedih, pesimistis dan kurang percaya diri. Tipe kepribadian melankolis yang kurang percaya diri dan pesimistis, pada umumnya akan kesulitan untuk menyelesaikan soal matematika karena mereka tidak yakin akan kemampuannya sendiri.

\section{SIMPULAN DAN SARAN}

Kesimpulan yang dapat diambil yaitu: (1) disposisi matematis siswa dengan tipe kepribadian sanguinis masuk kategori baik. (2) disposisi matematis siswa dengan tipe kepribadian melankolis masuk dalam kategori baik. (3) Terdapat perbedaan antara tipe kepribadian sanguinis dan melankolis, dimana disposisi matematis siswa dengan tipe kepribadian sanguinis lebih baik daripada siswa dengan tipe kepribadian melankolis.

Saran yang diberikan sebagai berikut: (1) Bagi guru sebaiknya lebih mem-perhatikan tipe kepribadian masing-masing siswa. (2) Bagi siswa diharapkan lebih mempersiapkan diri dalam proses pembelajaran agar dapat memperoleh hasil pembelajaran yang baik di 
sekolah. (3) Penelitian ini juga dapat dijadikan acuan untuk mengembangkan penelitian selanjutnya.

\section{DAFTAR RUJUKAN}

Diningrum, P. R., Azhar, E., \& Faradillah, A. (2018). Hubungan Disposisi Matematis terhadap Kemampuan Komunikasi Matematis Siswa Kelas VII di SMP Negeri 24. Prosiding Seminar Nasional Pendidikan Matematika 2018, Vol. 1, 352-364. Retrieved from http:/ / wwn.journal.ubamka.ac.id/index.php/senamku/article/view/2757.

Liaw, P. (2010). Understanding Your Communication Styles. Jakarta: PT. Gramedia.

Littauer, F. (2011). Personality Plus. Tangerang Selatan: Karisma Publishing Grup.

Prasetyo, A., Dwidayati, N., \& Junaedi, I. (2017). Students's Mathematical Connection Ability and Disposition Reviewed by Keirsey Personality Type through Eliciting Activities Mathematics Learning Model. Unnes Journal of Mathematics Education, 6(2), 190-197. https://doi.org/10.15294/ujme.v6i2.14301

Sjarkawi. (2006). Pembentukan Kepribadian Anak. Jakarta: PT Bumi Aksara.

Sugiyono. (2016). Metode Penelitian Kuantitatif, Kualitatif dan R\&D. Bandung: ALFABETA.

Sukamto. (2013). Strategi Quantum Learning dengan Pendekatan Konstruktivisme untuk Meningkatkan Disposisi dan Penalaran Matematis Siswa. Journal of Primary Educational, 2(2), 91-98.

Sumarmo, U. et al. (2012). Kemampuan dan Disposisi Berpikir Logis, Kritis, dan Kreatif Matematik (Eksperimen terhadap Siswa SMA Menggunakan Pembelajaran Berbasis Masalah dan Strategi Think-Talk-Write). Jurnal Pengajaran, 17(1), 17-33. DOI: http://dx.doi.org/10.18269/jpmipa.v17i1.228

Wardani, S. (2017). Perbandingan Hasil Belajar Biologi antara Siswa Kepribadian Sanguinis dan Kepribadian Melankolis Pada Kelas X Mia Sman 9 Makasar. Skripsi. Universitas Islam Negeri Alauddin Makasar.

Winarso, W. (2015). Perbedaan Tipe Kepribadian Siswa terhadap Sikap Belajar Matematika Siswa Kelas X SMA Al- Azhar 5 Cirebon. Jurnal Sainsmat, 4(1), 67-80.

Yusuf \& Nurihsan. (2012). Teori Kepribadian. Bandung: PT Remaja Rosdakarya. 